\title{
A case of subacute thyroiditis associated with Covid-19 infection
}

\author{
E. Asfuroglu Kalkan ${ }^{1} \cdot$ I. Ates ${ }^{1}$
}

Received: 13 May 2020 / Accepted: 27 May 2020 / Published online: 5 June 2020

(C) Italian Society of Endocrinology (SIE) 2020

To the Editor,

Subacute thyroiditis, is the most common cause of anterior cervical pain and is a self-limited disease [1]. Fever and radiating pain to the jaw, may also observed [2]. Subacute thyroiditis can be secondary to viral upper respiratory tract infection. Many viruses have been identified as the cause, such as coxsackie virus and adenovirus [3]. We describe a case of Covid-19-related subacute thyroiditis.

A 41-year-old Caucasian woman with no previous medical history was referred to internal medicine department with fever and neck pain. She denied having cough, shortness of breath, headache and new loss of taste or smell. She did not have a recent travel history and had not contacted anyone other than her parents. Clinical examination revealed erythematous pharyngitis, tenderness to palpation of thyroid, with normal size, and painful palpation of left temporomandibular joint and neck. General and systemic examination was unremarkable. Her body temperature was $101.3^{\circ} \mathrm{F}\left(38.5^{\circ} \mathrm{C}\right)$ and $101.12^{\circ} \mathrm{F}\left(38.4^{\circ} \mathrm{C}\right)$ at two separate measures. Laboratory investigations showed hemoglobin $12 \mathrm{~g} / \mathrm{dL}$, WBC 15,600, neutrophil 14,300, lymphocyte 800, erythrocyte sedimentation rate $134 \mathrm{~mm} / \mathrm{h}$, C-reactive protein $101 \mathrm{mg} / \mathrm{L}$, thyroid stimulating hormone $(\mathrm{TSH})<0.008$ $\mathrm{mIU} / \mathrm{L}$ in different measures. High free $\mathrm{T} 3$ of $7.7 \mathrm{pmol} / \mathrm{L}$ (3.1-6.8), high free T4 of $25.7 \mathrm{pmol} / \mathrm{L}$ (12-21). No TSH-R blocking, anti-thyroglobulin and anti-thyroperoxidase antibodies were detected. The respiratory viral panel was negative. Multiple sets of blood cultures, urine cultures, viral hepatitis serology, brucella and human immunodeficiency virus screening were negative. The real-time reverse transcription polymerase chain reaction (RT-PCR) of the

E. Asfuroglu Kalkan

emra.kalkan@hotmail.com

I. Ates

dr.ihsanates@hotmail.com

1 Department of Internal Medicine, Ankara City Hospital, Ankara, Turkey nasopharyngeal swab confirmed the diagnosis of Covid-19, two times. Chest X-rays and computed tomography scanning of the chest were normal. Thyroid ultrasound examination showed a relative diffuse decrease of vascularity and parenchyma was heterogeneous. Patient received hydroxychloroquine tablet $200 \mathrm{mg}$ bid for 5 days. Prednisolone $16 \mathrm{mg}$ daily was given and she showed significant improvement of clinical condition. She was discharged on prednisolone tapering dose for 4 weeks with outpatient follow-up.

The causal agent mainly based on serology, which made it difficult to differentiate between present and recent infection [3]. In this case, active infection with Covid-19 was confirmed since circulating viral genome was detected by RT-PCR.

A substantial number of patients with Severe Acute Respiratory Syndrome (SARS-CoV) have shown abnormalities in thyroid function. Follicular architecture was altered [4]. SARS could have harmful effect on the thyroid gland [5].

Physician should be aware of screening subacute thyroiditis patients for Covid-19 infection.

Author contributions All authors had access to the data and a role in writing the manuscript.

Funding No funding was provided to any of the author.

\section{Compliance with ethical standards}

Conflict of interest The authors declare that they have no conflict of interest.

Ethical Approval This article is a case report and written with the consent of the patient. Since this article is a case report, it does not contain any studies with animal or human participants performed by any of the authors.

Informed consent Informed consent has been obtained from the patient for publication of the case report. 


\section{References}

1. Zhao N, Wang S, Cui XJ, Huang MS, Wang SW, Li YG, Zhao L, Wan WN, Li YS, Shan ZY et al (2020) Two-years prospective follow-up study of subacute thyroiditis. Front Endocrinol (Lausanne) 28(11):47. https://doi.org/10.3389/fendo.2020.00047

2. Samuels MH (2012) Subacute, silent, and postpartum thyroiditis. Med Clin N Am 96(2):223-233

3. Desailloud R, Hober D (2009) Viruses and thyroiditis. An update. Virol J 6:5

4. Wei L, Sun S, Xu CH, Zhang J, Xu Y, Zhu H, Peh SC, Korteweg C, McNutt MA, Gu J (2007) Pathology of the thyroid in severe acute respiratory syndrome. Hum Pathol 38:95-102. https://doi. org/10.1016/j.humpath.2006.06.011

5. Wang W, Ye YX, Yao H (2003) Evaluation and observation of serum thyroid hormone and parathyroid hormone in patients with severe acute respiratory syndrome. J Chin Antituberculous Assoc 25:232-234

Publisher's Note Springer Nature remains neutral with regard to jurisdictional claims in published maps and institutional affiliations. 